\title{
Effect of Low Power Magnification on Total Occlusal Convergence Angles in Crown Preparation
}

\author{
Abdulrahman Almalki ${ }^{1}$, Sultan Almalki ${ }^{2}$, Tushar Bahgat ${ }^{3}$
}

\begin{abstract}
Purpose: The purpose of this study was to compare the total occlusal convergence angles of crown prepared teeth with low-power magnifying dental loupes and without dental loupes.

Materials and methods: Three different typodent maxillary teeth (incisor, premolar, and molar) were prepared with $\times 2.5$ dental loupes and other prepared without dental loupes. A total of 96 were made, 48 with dental loupes, 48 without dental loupes. Teeth were admitted for evaluation of the buccolingual and mesiodistal convergence angles of each prepared tooth with AutoCAD digital software.

Results: The average buccolingual and mesiodistal total convergence angles for crown-prepared central incisors with dental loupes were 14.73 degrees and 14.94 degrees without dental loupes. In premolars were 16.18 degrees with dental loupes and 17.74 without dental loupes. In molars were 18.55 degrees with dental loupes and 19.18 without dental loupes.

Conclusion: There is no statistically significant difference between crown-prepared teeth with $2.5 \mathrm{X}$ dental loupes and other crown-prepared teeth without dental loupes.

Keywords: Crown, Fixed prosthodontics, Magnification, Total occlusal convergence angles

International Journal of Prosthodontics and Restorative Dentistry (2019): 10.5005/jp-journals-10019-1225
\end{abstract}

\section{INTRODUCTION}

D evelopment in restorative dentistry places significant demands on the restorative dentists to work with a high level of visual acuity. A simple efficient way to achieve the better vision is by magnifying the area of interest. The use of magnification in dentistry has been advocated for many years. ${ }^{1}$ Many advantages have been reported for using magnification in clinical practice such as reducing diagnosis ambiguity, enhancing the clinical outcome, ensuring the maintenance of better posture, reducing visual stress, and decreasing musculoskeletal pain. ${ }^{2-4}$ Beside the clinician-centered benefits, magnifications could be beneficial in educational purposes. Robinson et al. 2001 showed that the use of magnification is an effective method in undergraduates' education by using video magnification for pre-clinical teaching of crown preparations. ${ }^{5}$ Maggio et al. concluded that dental magnification loupes significantly improve students' performance during preclinical dental teaching. ${ }^{6}$ Moreover, a study conducted by Leknius et al. 1995 revealed that dental students who used dental magnification in fixed prosthodontics procedures tended to have fewer errors than students who not use magnification. ${ }^{7}$ However, the disadvantages of dental magnifications are a psychological dependency, eye readjustment to normal vision after using dental magnification, considerably high cost, and relatively prolong learning curve..$^{8-10}$

The most common magnification devices that have been introduced in dentistry are loupes, surgical microscopes, and recently endoscopes with a wide range of magnification. ${ }^{11,12}$ The more sophisticated delicate procedures the high magnification power is required. Therefore, the high power of magnifications more frequently used in endodontics. In tooth preparation and other prosthodontics works the common magnification used is $\times 2.5$. $^{8}$

Tooth preparation has specific geometrical characteristics to provide essential retention and resistance. ${ }^{13}$ The most significant factor that contributes to the retention and resistance is total occlusal convergence (TOC) ${ }^{14}$ TOC has been defined as the converging angle of two opposite axial walls. While taper refers to the inclination of one wall of preparation to the long axis of a tooth (Fig. 1). ${ }^{15}$
${ }^{1}$ Faculty, ${ }^{2}$ Assistant Professor, ${ }^{3}$ Lecturer

${ }^{1,3}$ Department of Prosthetic Dental Science, Prince Sattam-bin Abdulaziz University, Alkarj, Riyadh, Kingdom of Saudi Arabia

${ }^{2}$ Department of Preventive Dentistry, Prince Sattam-bin Abdulaziz University, Alkarj, Riyadh, Kingdom of Saudi Arabia

Corresponding Author: Abdulrahman Almalki, Faculty, Department of Prosthetic Dental Science, Prince Sattam-bin Abdulaziz University, Alkarj, Riyadh, Kingdom of Saudi Arabia, e-mail: aa.almalki@psau.edu.sa

How to cite this article: Almalki A, Almalki S, Bahgat T. Effect of Low Power Magnification on Total Occlusal Convergence Angles in Crown Preparation. Int J Prosthodont Restor Dent 2019;9(1):13-17.

Source of support: Nil

Conflict of interest: None

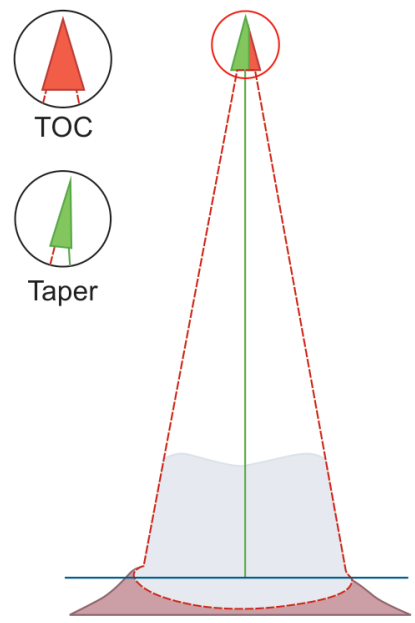

Fig. 1: Total occlusal convergence (TOC) is the angle formed between two opposing axial walls (red color), while taper is the angle formed between one axial wall with the long axis of tooth (green color)

(C) The Author(s). 2019 Open Access This article is distributed under the terms of the Creative Commons Attribution 4.0 International License (https://creativecommons. org/licenses/by-nc/4.0/), which permits unrestricted use, distribution, and non-commercial reproduction in any medium, provided you give appropriate credit to the original author(s) and the source, provide a link to the Creative Commons license, and indicate if changes were made. The Creative Commons Public Domain Dedication waiver (http://creativecommons.org/publicdomain/zero/1.0/) applies to the data made available in this article, unless otherwise stated. 
The oretically, parallel axial walls provide maximum retention and resistance. However, it is difficult to achieve this parallelism without undercut creation. ${ }^{16}$ Many studies showed a significant relation between total occlusal convergence and the retention and resistance of restoration on the prepared tooth. ${ }^{17,18}$ The optimal total occlusal convergence ranged from two degrees to 5.5 degrees. ${ }^{19-21}$ Other studies concluded that clinically achievable TOC range from 6 to 24 degrees. $^{13,18,22}$

This study measured the TOC angles on crown-prepared teeth aided by $x 2.5$ dental loupes and crown-prepared teeth by naked eyes. Even though many studies have discussed the application of dental loupes on several dental procedures, there was no single study correlate the relation between dental loupes and total occlusal convergence angles for crown-prepared teeth. The goal of the study was to test the null hypothesis that there would not be a significant difference between TOC angles of crown-prepared teeth aided by dental loupes and without dental loupes.

\section{Materials and methods}

This cross-sectional study was conducted at College of Dentistry, Prince Sattam-bin Abdulaziz University (PSAU), crown preparations were done by staff members in the phantom lab on typodont plastic teeth (Columbia model, Long Island City, New York, United States). The participants were asked to prepare three typodont teeth (Columbia model, Long Island City, New York, United States) as shown in Table 1. All other teeth were placed in the artificial jaws and mounted in the phantom head in the dental simulation units. The hand-pieces and burs were also standardized. Indirect visualization by dental mirrors was provided. Total preparation teeth were 96 (48 prepared teeth without dental loupes, and 48 prepared teeth with x2.5 dental loupes).

Custom-fit die bases were fabricated by light cure acrylic resin (Zermack, Padua, Italy) and marked to ensure the reproducibility of die positions (Fig. 2). Three bases were made for each tooth. Then, custom-fit die bases enabled the insertion and removal of the rest of the specimens in the accurately identical position every time.

Images were captured by a digital camera (Canon; EOS D700) with a macro lens (Canon EF 100mm f/2.8 Macro USM USM Fixed Lens for Canon SLR Cameras), which is mounted on a mini tripod and wireless remote control (Canon RC-6) at a distance $30 \mathrm{~cm}$ from the base. A black background was set up to increase the contrast between the background and the tooth. For each tooth, four pictures were taken in different standardized positions.

The images were transferred into a computer and AutoCAD 2017 for Mac software (version: 4.4.2) was used to measure the mesiodistal (MD) and buccolingual (BL) convergence angles. The two angles were measured by the mean of two opposing standardized positions. Measurement was including the gingival portion of tooth preparation due to its effectiveness in retention and resistance (Fig. 3). ${ }^{19}$

Paired (samples) t-test was used to assess if the means of the TOC angles for the crown-prepared teeth with dental loupes were statistically significantly different from crown-prepared teeth that were not aided by dental loupes.

Next, two analyses were carried out for each teeth type (incisors, premolar or molars). First Paired t-test was used to assess if the mean TOCs of Buccolingual crown-prepared teeth aided by dental loupes was statistically significantly different from crown-prepared teeth not aided by dental loupes. Then, the same test was repeated to

Table 1: Different types of crown-prepared teeth

\begin{tabular}{lllll}
\hline Artificial teeth & $\begin{array}{l}\text { Dental } \\
\text { loupes }\end{array}$ & $\begin{array}{l}\text { Without } \\
\text { dental loupes }\end{array}$ & $\begin{array}{l}\text { Total number of } \\
\text { prepared crowns }\end{array}$ & Type of tooth preparation \\
\hline $\begin{array}{l}\text { Maxillary right } \\
\text { central incisors }\end{array}$ & 16 & 16 & 32 & $\begin{array}{l}\text { Full ceramic crown } \\
\text { preparation }\end{array}$ \\
$\begin{array}{l}\text { Maxillary right } \\
\text { first premolar }\end{array}$ & 16 & 16 & 32 & $\begin{array}{l}\text { Porcelain fused to metal } \\
\text { crown preparation }\end{array}$ \\
$\begin{array}{l}\text { Maxillary right } \\
\text { first molar }\end{array}$ & 16 & 16 & 32 & $\begin{array}{l}\text { Full metal crown } \\
\text { preparation }\end{array}$ \\
\hline
\end{tabular}

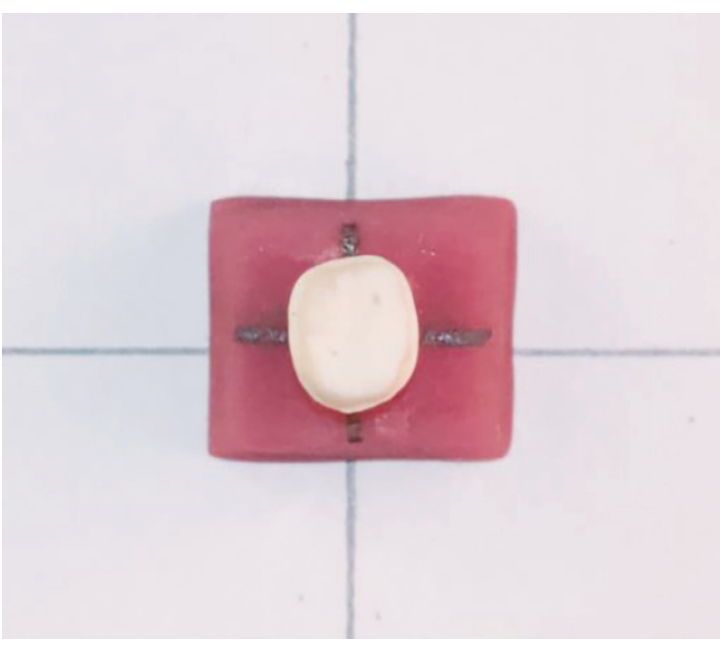

Fig. 2: Custom-fit bases marked to ensure reproducibility of the tooth and die position

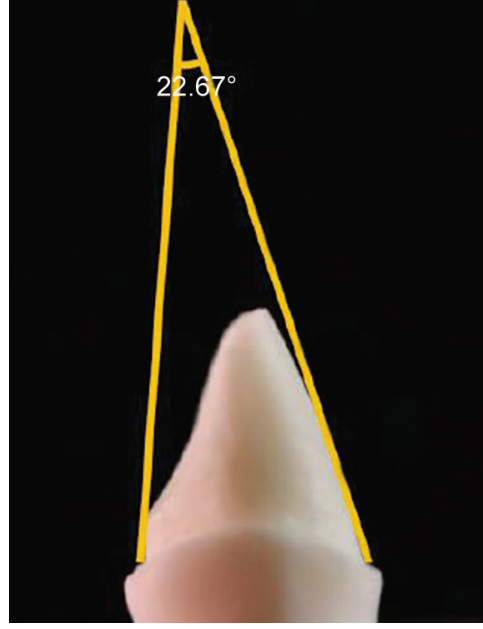

Fig. 3: Measuring total occlusal convergence 
assess if the mean TOCs of mesiodistal crown-prepared teeth aided by dental loupes was statistically significantly different from crownprepared teeth not aided by dental loupes.

\section{Results}

Each side and tooth analyzed separately, the results Table 2 indicate that the mean TOC angles of buccolingual (BL), and mesiodistal (MD) of incisor teeth were not statistically significantly different between incisor-prepared with dental loupes and without dental loupes ( $p=0.7462$, and $p=0.9418$, respectively). In premolars, the results also indicate that the mean TOC angles of crown-prepared premolar teeth with dental loupes was not statistically significantly different from crown-prepared teeth without dental loupes for both BL and MD sides ( $p=0.9151$ and 0.1251 , respectively). In molars, the results indicate that the mean TOC angles of crown-prepared molar teeth with dental loupes was not statistically significantly different from crown-prepared teeth without dental loupes for both BL and MD sides ( $p=0.7680$ and 0.2051 , respectively).

The average $\mathrm{BL}$ and $\mathrm{MD}$ convergence angles for crownprepared central incisors with dental loupes were 14.73 degrees and 14.94 degrees without dental loupes. Among premolars were 16.18 degrees with dental loupes and 17.74 without dental loupes. Among molars group were 18.55 degrees with dental loupes and 19.18 without dental loupes.

\section{Discussion}

Because no significant differences were found between convergence angles in each group of crown-prepared teeth, the null hypothesis was confirmed. In the previous study, magnifications were extensively discussed in endodontics and periodontics. ${ }^{23,24}$ In restorative dentistry, few studies have addressed the effect of magnifications, they discussed the magnification effect on iatrogenic damage to the adjacent tooth surface, ${ }^{25}$ geometrical shapes, ${ }^{26}$ and ergonomic benefits. ${ }^{27}$ No single study was found that discussed the effect of magnifications in total occlusal convergence for crown-prepared teeth.

Magnification of $\times 2.5$ provides a multiple quadrant field view focus. ${ }^{3}$ This is adequate for most restorative procedures and is the recommended magnification for new users. ${ }^{3,8}$ At magnification $\times 3.5$ or higher, the view filed becomes increasingly restricted until the only single tooth is seen, this makes high magnification unsuitable for all restorative works. ${ }^{3}$ In crown-prepared teeth, the clinician must see the abutment and adjust teeth to avoid any unnecessary damage. Thus, $x 2.5$ is the recommended magnification for crownteeth preparation. In this study, standardized $\times 2.5$ dental loupes were used by the all participant during the crown preparations.

Several techniques have been described for evaluating total occlusal convergence for crown-prepared crowns. Light projection and silhouette tracing, ${ }^{28-31}$ projected photograph negatives, ${ }^{32,33}$ photographs, ${ }^{34}$ photocopies of the shadow dies, ${ }^{35}$ microscopes, ${ }^{36,37}$ and three-dimensional laser scanners. ${ }^{17}$ In this study, the AutoCAD software for the evaluation of the photographs was utilized which has been previously used by Ghafoor et al., ${ }^{17}$ and Al Ali et al. ${ }^{38}$

Although several studies have acknowledged that ideal TOC angles are rarely achieved. Parker et al. mentioned that the minimal acceptable average convergence angles are 29-degree for incisors, 33 degree for canines, 10 degree for premolars, and 8.4 degree for molars. ${ }^{39}$ Also, Goodacre et al. recommended 10 to 20 degrees as an ideal TOC. ${ }^{40,41}$ Other studies reporting TOC angles are summarized in Table 3. In this study, the total occlusal convergence

Table 2: Means TOC angles for crown-prepared teeth

\begin{tabular}{lllll}
\hline & & \multicolumn{2}{l}{ Means TOC angles (95\% Confidence interval) } & \\
\cline { 3 - 4 } Type of teeth & Side & Aided by dental loupes & Not aided by dental loupes & \\
\hline Incisors & $\mathrm{BL}$ & $19.83(17.98-21.69)$ & $20.16(18.91-21.41)$ & 0.75 \\
& $\mathrm{MD}$ & $9.63(7.64-11.62)$ & $9.72(8.44-11.00)$ & 0.94 \\
\hline Premolars & $\mathrm{BL}$ & $17.33(14.99-19.66)$ & $17.25(16.01-18.48)$ & 0.91 \\
& $\mathrm{MD}$ & $15.02(12.28-17.75)$ & $18.22(14.82-21.62)$ & 0.12 \\
\hline Molars & $\mathrm{BL}$ & $17.46(15.82-19.09)$ & $17.80(16.24-19.37)$ & 0.77 \\
& $\mathrm{MD}$ & $19.64(18.2-21.08)$ & $20.55(18.70-22.39)$ & 0.20 \\
\hline
\end{tabular}

Table 3: Summary of average TOC angles in the literature review

\begin{tabular}{|c|c|c|c|c|c|}
\hline \multirow[b]{2}{*}{ Study/Year } & \multirow[b]{2}{*}{ Tooth type } & \multirow{2}{*}{$\begin{array}{l}\text { Preparation } \\
\text { crown types }\end{array}$} & \multicolumn{2}{|c|}{$\begin{array}{l}\text { Total occlusal convergence in } \\
\text { degree (SD) }\end{array}$} & \multirow[t]{2}{*}{ Operator } \\
\hline & & & Buccolingual & Mesiodistal & \\
\hline $\begin{array}{l}\text { Marghalani, } \\
2014 .^{40}\end{array}$ & Premolars & Metal ceramic & $10.49(3.95)$ & $11.11(4.79)$ & $\begin{array}{l}\text { 5th year dental } \\
\text { students }\end{array}$ \\
\hline \multirow{3}{*}{$\begin{array}{l}\text { Yoon, } \\
2014 .{ }^{15}\end{array}$} & Incisors & Full ceramic & 20.4 & 6.3 & \multirow{3}{*}{$\begin{array}{l}\text { 3rd and 4th year } \\
\text { dental students }\end{array}$} \\
\hline & Premolars & Metal ceramic & 12.4 & 10.6 & \\
\hline & Molars & Full metal & 16.3 & 16.9 & \\
\hline $\begin{array}{l}\text { Al-Dwairi, } \\
2015 .^{42}\end{array}$ & Molars & Metal ceramic & 29.8 & 24.7 & $\begin{array}{l}\text { GDPs and } \\
\text { specialists }\end{array}$ \\
\hline \multirow{3}{*}{$\begin{array}{l}\text { Janine, } \\
2016 .{ }^{43}\end{array}$} & Incisors & Metal ceramic & $19.61(12.50)$ & $13.51(7.82)$ & \multirow{3}{*}{$\begin{array}{l}\text { Post-doctorate } \\
\text { students and staff } \\
\text { members }\end{array}$} \\
\hline & Premolars & Metal ceramic & $12.0(10.64)$ & $14.26(6.95)$ & \\
\hline & Molars & Metal ceramic & $14.26(6.95)$ & $14.54(9.05)$ & \\
\hline
\end{tabular}


angles for crown-prepared central incisors with dental loupes were 14.73 degrees and 14.94 degrees without dental loupes. Among premolars were 16.18 degrees with dental loupes and 17.74 without dental loupes. Among molars group were 18.55 degrees with dental loupes and 19.18 without dental loupes. These results are fall in the ideal range because of the participants of this study were experienced staff members. In compared to other studies, most of the participants were students. ${ }^{15,41,42}$

This study has some limitations, and teeth preparation was performed on artificial teeth. Therefore, the variable of patient compliance, accessibility, and soft tissue were not present. Then, the convergence angles achievability could differ from clinical situations. Hopefully, future studies may consider more clinical sample size, and reporting other aspects of crown-prepared teeth.

\section{Conclusion}

This is in vitro study comparing TOC values of crown-prepared teeth with $\times 2.5$ dental loupes and without dental loupes among three different teeth found that there was no significant difference between crown-prepared teeth with $\times 2.5$ dental loupes and without dental loupes.

\section{References}

1. Caplan SA. Magnification in dentistry. J Esthet Dent. 1990;2(1): 17-21.

2. Mamoun JS. A rationale for the use of high-powered magnification or microscopes in general dentistry. Gen Dent. 2009;57(1):18-26.

3. James T, Gilmour AS. Magnifying loupes in modern dental practice: an update. Dent update.2010;37(9):633-636.

4. Maillet JP, Millar AM, Burke JM, et al. Effect of magnification loupes on dental hygiene student posture. J Dent Edu. 2008;72(1):33-44.

5. Robinson PB, Lee JW. The use of real time video magnification for the pre-clinical teaching of crown preparations. Br Dent J. 2001;190(9):506-510.

6. Maggio MP, Villegas $\mathrm{H}$, Blatz MB. The effect of magnification loupes on the performance of preclinical dental students. Quintessence Int.2011;42(1):45-55.

7. Leknius $C$, Geissberger M. The effect of magnification on the performance of fixed prosthodontic procedures. J Calif Dent Assoc.

8. Christensen GJ. Magnification in dentistry: useful tool or another gimmick? J Am Dent Assoc.2003;134(12):1647-1650.

9. Del Fabbro M, Taschieri S, Lodi G, et al. Magnification devices for endodontic therapy.Cochrane Database Syst Rev.2009(3):Cd005969.

10. Friedman MJ. Magnification in a restorative dental practice: from loupes to microscopes. Compend Contin Educ Dent.2004;25(1): 53-55.

11. Khayat BG. The use of magnification in endodontic therapy: the operating microscope. Pract Periodontics Aesthet Dent.1998;10(1):137144.

12. Behle C. Photography and the operating microscope in dentistry. J Calif Dent Assoc.2001;29(10):765-771.

13. Shillingburg HT, Hobo $S$, Whitsett $L D$, et al.Fundamentals of fixed prosthodontics. 3rd ed: Chicago: Quintessence Publishing; 1997:119138.

14. Tiu J, Al-Amleh B, Waddell JN, et al. Clinical tooth preparations and associated measuring methods: a systematic review. J Prosthet Dent. 2015;113(3):175-184.

15. Yoon SS, Cheong C, Preisser J, Jr.,et al. Measurement of total occlusal convergence of 3 different tooth preparations in 4 different planes by dental students. J Prosthet Dent 2014;112(2):285-292.

16. Rosella D, Rosella G, Brauner E, et al. A tooth preparation technique in fixed prosthodontics for students and neophyte dentists. Annali di stomatologia. 2015;6(3-4):104-109.
17. Chan DC, Wilson AH, Jr., Barbe $P$, et al. Effect of preparation convergence on retention and seating discrepancy of complete veneer crowns. J Oral Rehabil. 2005;32(1):58-64.

18. Wilson AH, Jr., Chan DC. The relationship between preparation convergence and retention of extracoronal retainers. J Prosthodont.1994;3(2):74-78.

19. Kaufman EG, Coelho DH, Colin L. Factors influencing the retention of cemented gold castings. J Prosthet Dent.11(3):487-502.

20. Gilboe DB, Teteruck WR. Fundamentals of extracoronal tooth preparation. Part I. Retention and resistance form. J Prosthet Dent. 1974;32(6):651-656.

21. el-Ebrashi MK, Craig RG, Peyton FA. Experimental stress analysis of dental restorations. IV. The concept of parallelism of axial walls. J Prosthet Dent. 1969;22(3):346-353.

22. Rosenstiel SF, Land M, Fujimoto J. Contemporary fixed prosthodontics 5th ed: Mosby Elsevier; 2006.

23. Park E, Chehroudi B, Coil JM. Identification of possible factors impacting dental students' ability to locate MB2 canals in maxillary molars. J Dent Edu. 2014;78(5):789-795.

24. Perrin P, Neuhaus KW, Lussi A. The impact of loupes and microscopes on vision in endodontics. Int Endod J. 2014;47(5):425-429.

25. Lussi $A$, Kronenberg $O$, Megert $B$. The effect of magnification on the iatrogenic damage to adjacent tooth surfaces during class II preparation. J Dent. 2003;31(4):291-296.

26. Eichenberger $M$, Biner $N$, Amato $M$, et al. Effect of magnification on the precision of tooth preparation in dentistry. Oper Dent. 2018;43(5):501507.

27. Valachi B, Valachi K. Preventing musculoskeletal disorders in clinical dentistry: strategies to address the mechanisms leading to musculoskeletal disorders. J Am Dent Assoc.2003;134(12):1604-1612.

28. Sato T, Al Mutawa N, Okada D, Hasegawa S. A clinical study on abutment taper and height of full cast crown preparations. J Med Dent Sci. 1998;45(3):205-210.

29. Nordlander J, Weir D, Stoffer W, et al. The taper of clinical preparations for fixed prosthodontics. J Prosthet Dent.1988;60(2):148-151.

30. Smith CT, Gary JJ, Conkin JE, et al. Effective taper criterion for the full veneer crown preparation in preclinical prosthodontics. J Prosthodont.1999;8(3):196-200.

31. Poon BK, Smales RJ. Assessment of clinical preparations for single gold and ceramometal crowns. Quintessence Int.2001;32(8): 603-610.

32. Leempoel PJ, Lemmens PL, Snoek PA, et al. The convergence angle of tooth preparations for complete crowns. J Prosthet Dent. 1987;58(4):414-416.

33. Kent WA, Shillingburg HT, Jr., Duncanson MG, Jr. Taper of clinical preparations for cast restorations. Quintessence Int.1988;19(5):339345.

34. Noonan JE, Jr., Goldfogel MH. Convergence of the axial walls of full veneer crown preparations in a dental school environment. J Prosthet Dent.1991;66(5):706-708.

35. Al-Omari WM, Al-Wahadni AM. Convergence angle, occlusal reduction, and finish line depth of full-crown preparations made by dental students. Quintessence Int.2004;35(4):287-293.

36. Ayad MF, Maghrabi AA, Rosenstiel SF. Assessment of convergence angles of tooth preparations for complete crowns among dental students. J Dent.2005;33(8):633-638.

37. Al Ali K, Al Wazzan KA, Al Amri MA et al. Assessment of convergence angle of full veneer preparations carried out by practitioners with different levels of experience. S Dent J.2009;21:37-44.

38. Parker MH, Calverley MJ, Gardner FM, et al. New guidelines for preparation taper. J Prosthodont.1993;2(1):61-66. 
39. Goodacre CJ, Campagni WV, Aquilino SA. Tooth preparations for complete crowns: an art form based on scientific principles. J Prosthet Dentist.2001;85(4):363-376.

40. Marghalani TY. Convergence angles of metal ceramic crowns prepared by dental students. J Prosthet Dent. 2014;112(5):1250-1256.

41. Tran J, Dudley J, Richards L. All-ceramic crown preparations: An alternative technique. Aus Dent J.2017;62(1):65-70.
42. Al-Dwairi ZN, Bashatwa MM, Lynch E. Assessment of posterior teeth preparations for metal-ceramic crowns. Eur J Prosthodont Restor Dent.2015;23(3):P141-P149.

43. Tiu J, Lin T, Al-Amleh B, Waddell JN. Convergence angles and margin widths of tooth preparations by New Zealand dental students. J Prosthet Dent. 2016;116(1):74-79. 